\title{
Angiotensin-converting enzyme inhibition by lisinopril enhances liver regeneration in rats
}

\section{F.S. Ramalho ${ }^{1}$, \\ L.N.Z. Ramalho², \\ O. Castro-e-Silva Júnior ${ }^{1}$, \\ S. Zucoloto ${ }^{2}$ and \\ F.M.A. Corrêa ${ }^{3}$}

\author{
Departamentos de ${ }^{1} \mathrm{C}$ irurgia, ${ }^{2}$ Patologia and ${ }^{3}$ Farmacologia, \\ Faculdade de Medicina de Ribeirão Preto, U niversidade de São Paulo, \\ Ribeirão Preto, SP, Brasil
}

\section{Correspondence \\ O. Castro-e-Silva Júnior Departamento de Cirurgia FMRP, USP \\ Av. Bandeirantes, 3900 14049-900 Ribeirão Preto, SP Brasil \\ Fax: + 55-16-602-2870 \\ E-mail: orlandocsj@ hotmail.com \\ Presented at the 4th World Congress of the International Hepato-Pancreato-Biliary Association, May 28-June 1 2000, Brisbane, Australia.}

Research supported by FAPESP.

Received M arch 20, 2000 Accepted October 31, 2000

\section{Abstract}

Bradykinin has been reported to act as a growth factor for fibroblasts, mesangial cells and keratinocytes. Recently, we reported that bradykinin augments liver regeneration after partial hepatectomy in rats. Angiotensin-converting enzyme (ACE) is also a powerful bradykinindegrading enzyme. We have investigated the effect of ACE inhibition by lisinopril on liver regeneration after partial hepatectomy. Adult male Wistar rats underwent $70 \%$ partial hepatectomy $(\mathrm{PH})$. The animals received lisinopril at a dose of $1 \mathrm{mg} \mathrm{kg}$ body weight $^{-1}$ day $^{-1}$, or saline solution, intraperitoneally, for 5 days before hepatectomy, and daily after surgery. Four to six animals from the lisinopril and saline groups were sacrificed at 12, 24, 36, 48, 72, and $120 \mathrm{~h}$ after PH. Liver regeneration was evaluated by immunohistochemical staining for proliferating cell nuclear antigen using the PC-10 monoclonal antibody. The value for the lisinopril-treated group was three-fold above the corresponding control at $12 \mathrm{~h}$ after $\mathrm{PH}(\mathrm{P}<0.001)$, remaining elevated at approximately two-fold above control values at 24, 36, 48 $(\mathrm{P}<0.001)$, and at $72 \mathrm{~h}(\mathrm{P}<0.01)$ after $\mathrm{PH}$, but values did not reach statistical difference at $120 \mathrm{~h}$ after PH. Plasma ACE activity measured by radioenzymatic assay was significantly higher in the saline group than in the lisinopril-treated group $(\mathrm{P}<0.001)$, with $81 \%$ ACE inhibition. The present study shows that plasma ACE inhibition enhances liver regeneration after $\mathrm{PH}$ in rats. Since it was reported that bradykinin also augments liver regeneration after $\mathrm{PH}$, this may explain the liver growth stimulating effect of ACE inhibitors.

Liver regeneration is a unique phenomenon in which the loss of hepatic tissue rapidly induces an orchestrated response involving sequential changes in gene expression, growth factor production, and morphologic structure $(1,2)$. Several substances with potentially important roles in liver regenera- tion have been recently identified (2). The kallikrein-kinin system exerts a variety of biological effects, including vasodilatation, increased vascular permeability and smooth muscle relaxation or contraction (3-5). Bradykinin has been reported to act as a growth factor for several cell types, such as mesangi-

\section{Key words}

- Angiotensin-converting enzyme inhibitors

- Lisinopril

- Bradykinin

- Liver regeneration

- Cell proliferation

- Hepatocyte 
al cells (6), keratinocytes (7), and fibroblasts (8). We reported that bradykinin augments liver regeneration after partial hepatectomy in rats (9). Angiotensin-converting enzyme (ACE) is also known as kininase II, a powerful bradykinin-degrading enzyme (3). ACE inhibitors have two main mechanisms of action: the simultaneous prevention of angiotensin II production and bradykinin degradation (4).

In this study, we have investigated the effect of ACE inhibition by lisinopril on liver regeneration. Male Wistar rats (180$220 \mathrm{~g}$ ) underwent $70 \%$ partial hepatectomy (PH) as described by Higgins and Anderson (10). The rats received lisinopril (MK 521; Merck, White House Station, NJ, USA) at a dose of $1 \mathrm{mg} \mathrm{kg}$ body weight $^{-1}$ day $^{-1}$, or saline solution in a proportional volume, intraperitoneally, for 5 days before hepatectomy, and daily after surgery. Plasma ACE activity was measured by radioenzymatic assay according to the method of Ryan et al. (11). Four to six animals from the lisinopril and saline groups were sacrificed under ether anesthesia at 12, 24, 36, 48, 72, and $120 \mathrm{~h}$ after PH. Sham operations consisting of laparotomy and manipulation of the liver were also carried out. Just before $\mathrm{PH}$ and $24 \mathrm{~h}$ after $\mathrm{PH}$, blood samples $(2 \mathrm{ml} / \mathrm{kg})$ were collected for measurement of ACE activity, and mean arterial blood pressure was monitored for 30 min via a catheter placed into the left femoral artery (5 animals per group).

Liver regeneration was evaluated by im-

Figure 1 - Effect of lisinopril on nuclear labeling index by proliferating cell nuclear antigen (PCNA) immunostaining. Lisinopril- and saline-treated rats were sacrificed at $12,24,36,48,72$ and $120 \mathrm{~h}$ after $70 \%$ partial hepatectomy. Each point represents the mean \pm SEM ( 4 to 6 animals per group). The nuclear labeling index for sham-operated rats was $1.08 \pm 0.15 \%(\mathrm{~N}=5)$. $* \mathrm{P}<0.01, * * \mathrm{P}<0.001$ compared to saline-treated group (Student t-test). ing cell nuclear antigen (PCNA) using monoclonal primary anti-PCNA antibody (PC-10; DAKO A/S, Glostrup, Denmark) on formalin-fixed and paraffin-embedded liver tissues (12-14). Sections were cut at $4 \mu \mathrm{m}$, mounted on poly-L-lysine-coated glass slides, deparaffinized, rehydrated in an increasing alcohol series, placed in PBS, and treated with $2 \%$ hydrogen peroxide in methanol for 15 min to block endogenous peroxidase activity.

Nonspecific protein binding was blocked by preincubation with $5 \%$ normal horse serum diluted in PBS for $30 \mathrm{~min}$. This was followed by incubation with PC-10 monoclonal primary antibody, diluted 1:40 in PBS for $120 \mathrm{~min}$ at $25^{\circ} \mathrm{C}$. The sections were then incubated for $35 \mathrm{~min}$ with a biotinylated horse antimouse immunoglobulin. The reaction product was detected with an avidinbiotin-peroxidase complex and diaminobenzidine was used as a chromogen substrate. Positive and negative controls were used to assess and control the staining procedure. Sections were examined blindly at high power (400X), and 10 fields were chosen at random. Nuclear labeling indices for PCNA (positive nuclei/total number of counted nuclei) were determined by evaluation of at least 1,000 hepatocyte nuclei. Data are reported as mean \pm SEM. The Student $t$-test was used for statistical analysis of the data.

The results concerning the PCNA labeling index were quite consistent (Figure 1). The value for the lisinopril-treated group was three-fold above the corresponding control at $12 \mathrm{~h}(\mathrm{P}<0.001)$, remaining elevated at approximately two-fold above control values at 24, 36, $48(\mathrm{P}<0.001)$, and at $72 \mathrm{~h}$ $(\mathrm{P}<0.01)$, but values were not significantly different at $120 \mathrm{~h}(\mathrm{P}=0.47)$. Plasma ACE activity was significantly higher in the saline group $\left(112.24 \pm 12.22 \mathrm{nmol} \mathrm{mg} \mathrm{protein}{ }^{-1} \mathrm{~h}^{-1}\right)$ than in the lisinopril-treated group $(21.82 \pm$ $5.14 \mathrm{nmol} \mathrm{mg} \mathrm{protein}{ }^{-1} \mathrm{~h}^{-1} ; \mathrm{P}<0.001$ ), with an $81 \%$ rate of ACE inhibition. The values of mean arterial blood pressure were not signif- 
icantly different $(106 \pm 2 \mathrm{mmHg} v s \quad 104 \pm 2$ $\mathrm{mmHg}$ ).

The present study shows that ACE inhibition enhances liver regeneration after $\mathrm{PH}$. In addition to inhibiting the renin-angiotensin system, ACE inhibitors potentiate the biological actions of kinins (4). It was reported that bradykinin augments liver regeneration after PH (9), which may explain the liver growth stimulating effect of ACE inhibitors. Recent investigations have reported that ACE inhibition increases renal hepatocyte growth factor (HGF) mRNA and cardiac HGF con- centration in experimentally hypertensive rats, and that angiotensin II downregulates HGF production in mesangial cells in a cultured model $(15,16)$. HGF was initially identified as the most potent growth factor for hepatocytes (17). Another interpretation of these data is that angiotensin II may also downregulate hepatocellular HGF production, and that hepatic HGF concentration might be elevated in response to ACE inhibition, potentially resulting in the improvement of liver regeneration.

\section{References}

1. Michalopoulos GK \& DeFrances MC (1997). Liver regeneration. Science, 276: 60-66.

2. LaBrecque $D$ (1994). Liver regeneration: a picture emerges from the puzzle. American J ournal of Gastroenterology, 89: S86S96.

3. Regoli $D \&$ Barabé J (1980). Pharmacology of bradykinin and related kinins. Pharmacological Reviews, 32: 1-46.

4. Ito K, Zhu Y, Gohlke P \& Unger T (1997). Contribution of bradykinin to the cardioprotective action of angiotensin converting enzyme inhibition in hypertension and after myocardial infarction. J apanese J ournal of Pharmacology, 75: 311-318.

5. Coutant KD \& Ryder NS (1996). Bradykinin upregulates immediate-early gene mRNA in human keratinocytes. Archives of Dermatological Research, 288: 2-6.

6. Girolami J P, Ouardani M, Bascands J L, Pécher C, Bompart G \& Leung-Tack J (1995). Comparison of B1 and B2 receptor activation on intracellular calcium, cell proliferation, and extracellular collagen secretion in mesangial cells from normal and diabetic rats. Canadian J ournal of Physiology and Pharmacology, 73: 848-853.

7. Talwar HS, Fisher GJ \& Voorhees JJ (1990). Bradykinin induces phosphoinositide turnover, 1,2-diglyceride formation, and growth in cultured adult human keratinocytes. J ournal of Investigative Dermatology, 95: 705-710.

8. Goldstein RH \& Wall M (1984). Activation of protein formation and cell division by bradykinin and des-Arg-bradykinin. J ournal of Biological Chemistry, 259: 92639268.

9. Castro-e-Silva J r O, Ramalho FS, Ramalho LNZ, Correa FMA \& Zucoloto S (1999). Effect of bradykinin on liver regeneration. In: M oreno-Gonzáles E \& Hidalgo-Pascual M (Editors), Proceedings of the 3rd World Congress of the International Hepato-Pancreato-Biliary Association. J arpyo Editores, Madrid, 193-195.

10. Higgins GM \& Anderson RM (1931). Experimental pathology of the liver: I. Restoration of the liver of the white rat following partial surgical removal. Archives of Pathology, 12: 186-202.

11. Ryan J W, Chung A, Ammons C \& Carlton ML (1977). A simple radioassay for angiotensin-converting enzyme. Biochemical J ournal, 167: 501-504.

12. Wolf HK \& Michalopoulos GK (1992). Hepatocyte regeneration in acute fulminant and nonfulminant hepatitis: a study of proliferating cell nuclear antigen expression. Hepatology, 15: 707-713.

13. Chijiiwa K, Nakano K, Kamoeka N, Nagai E
\& Tanaka M (1994). Proliferating cell nuclear antigen, plasma fibronectin, and liver regeneration rate after seventy percent hepatectomy in normal and cirrhotic rats. Surgery, 116: 544-549.

14. Assy N, Gong Y, Zhang M, Pettigrew NM, Pashniak D \& Minuk GY (1998). Use of proliferating cell nuclear antigen as a marker of liver regeneration after partial hepatectomy in rats. J ournal of Laboratory and Clinical Medicine, 131: 251-256.

15. Nakano N, Moriguchi A, Morishita R, Kida I, Tomita N, Matsumoto K, Nakamura T, Higaki J \& Ogihara T (1997). Role of angiotensin II in the regulation of a novel vascular modulator, hepatocyte growth factor (HGF), in experimental hypertensive rats. Hypertension, 30: 1448-1454.

16. Matsumoto $K$, Morishita $R$, Moriguchi $A$, Tomita N, Yo Y, Nishii T, Matsumoto K, Nakamura T, Higaki J \& Ogihara T (1999). Prevention of renal damage by angiotensin II blockade accompanied by increased renal hepatocyte growth factor in experimental hypertensive rats. Hypertension, 34: 279-284.

17. Nakamura T, Nishizawa T, Hagiya M, Seki T, Shimonishi M, Sugimura A, Tashiro K \& Shimizu S (1989). Molecular cloning and expression of human hepatocyte growth factor. Nature, 342: 440-443. 